\title{
Evaluation of Clinical and Operative Characteristics of Patients Undergoing Laparoscopic and Open Simple Nephrectomy
}

\section{Laparoskopik ve Açık Basit Nefrektomi Yapılan Hastaların Klinik ve Operatif Özelliklerinin Değerlendirilmesi}

\author{
Ekrem Guner $\odot$, Yusuf Arikan $\odot$ \\ Health Science University, Bakirkoy Dr. Sadi Konuk Training and Research Hospital, Department of Urology, Istanbul, Turkey
}

Received: 1 April 2019 / Accepted: 4 January 2020 / Publication date: 26 June 2020

Cite as: Guner E, Arikan Y. Evaluation of clinical and operative characteristics of patients undergoing laparoscopic and open simple nephrectomy. Med J Bakirkoy 2020;16(2):148-51.

\begin{abstract}
Objective: We aimed to raise awareness of patient management by examining the clinical and operative characteristics of patients undergoing simple nephrectomy for benign pathologies.

Method: Data of patients who underwent simple nephrectomy for benign pathologies in our clinic between 2008-2019 were reviewed retrospectively. Demographic data, nephrectomy indications, renal scintigraphy results and operative characteristics of the patients were analyzed.

Results: A total of 90 patients (51 female and 39 male) were included in the study. The mean age of the patients was $45.1 \pm 14.6$ years. Fourty-eight of the nephrectomized kidneys were right kidney and 42 were left kidneys. Laparoscopic nephrectomy was performed in 47 (52.2\%) patients and open nephrectomy was performed in 43 (47.8\%) patients. A total of 6 patients (6.6\%) had peroperative complications. There was no difference in peroperative complications in patients undergoing laparoscopic and open nephrectomy $(p=0.14)$. Patient ages, BMIs and operative times were similar; $p=0.535, p=0.337$ and $p=0.074$, respectively. Conclusion: Laparoscopic and open surgery provides similar surgical results in simple nephrectomies due to benign pathologies compared to the surgeon experience.
\end{abstract}

Keywords: simple nephrectomy, laparoscopic nephrectomy, non-functional kidney

öz

Amaç: Benign patolojiler sebebi ile basit nefrektomi yapılan hastaların klinik ve operatif özelliklerini incelemek sureti ile hasta yönetiminde farkındalık yaratmayı amaçladık.

Yöntem: 2008-2019 yılları arasında kliniğimizde benign patolojiler nedeniyle basit nefrektomi yapılan hastaların verileri geriye dönük olarak tarandı. Hastaların demografik verileri, nefrektomi endikasyonları, renal sintigrafi sonuçları, operatif özellikleri incelendi. Bulgular: Çalışmaya 39'u kadın ve 51'i erkek olmak üzere toplam 90 hasta dahil edildi. Hastaların ortalama yaşı $45.1 \pm 14.6$ yıl idi. Nefrektomi yapılan böbreklerin 48'i sağ böbrek iken 42 tanesi sol böbrek idi. Hastaların 47'sine (\%52.2) laparoskopik nefrektomi yapılırken 43'üne (\%47.8) açık nefrektomi yapıldı. Toplam 6 hastada $(\% 6,6)$ peroperatif komplikasyon izlendi. Laparoskopik ve açık nefrektomi yapılan hastalarda peroperatif komplikasyon açısından farklılık izlenmezken ( $p=0.14)$, hasta yaşları, VKi'leri ve operasyon süreleri benzer idi; sırasıly $p=0.535, p=0.337$ ve $p=0.074$.

Sonuç: Laparoskopik ve açık cerrahi benign nedenler dolayısı ile yapılan basit nefrektomilerde cerrah deneyimine göre benzer cerrahi sonuçlar sunmaktadır.

Anahtar kelimeler: ebasit nefrektomi, laparoskopik nefrektomi, non-fonksiyone böbrek 


\section{INTRODUCTION}

While simple nephrectomy is generally used to define nephrectomy done for benign pathologies, radical nephrectomy is a term used for nephrectomy done for malign diseases. This terminology actually causes misunderstandings. Although nephrectomy can be considered as an easier technique with less complications compared to radical nephrectomy based on this term, this is not the actual condition as accepted by many experienced surgeons. Especially nephrectomies related to severe pyelonephritis and stone disease can be more difficult and have complications compared to its radical conjugate ${ }^{[1,2]}$. Simple nephrectomy can be done in many different ways such as retroperitoneal, transperitoneal, open, laparoscopic, robot-assited ${ }^{[3,4,5]}$. Underlying pathology affects the operation characteristics.

Our aim in this study was to create awareness in patient management by examining clinical and operative characteristics of patients who had simple nephrectomy due to benign pathologies.

\section{MATERIAL and METHOD}

After taking the consent of local ethics board of our hospital, data of patients who had simple nephrectomy due to benign pathologies in our clinic between 2008 and 2019 were retrospectively scanned. Demographic data, nephrectomy indications, renal scintigraphy results and operative characteristics of the patients were examined. Male and female patients between the ages of 18 and 80 who had nephrectomy due to benign pathologies were included in the study. Patients who were under 18 years of age, had nephrectomy secondary to trauma and whose data were unreachable were excluded from the study. Patients were separated into two groups based on the operation type as open and laparoscopic.

\section{Statistical Analysis}

SPSS statistics package program version 21 was used for data analysis. While constant variables were given in mean \pm standard deviation, categorical variables were given in percentages. Mann-Whitney $U$ test was used for the comparison of the two groups. $\mathrm{P}<0.05$ was regarded as statistically significant.

\section{RESULTS}

A total of 90 patients including 39 male and 51 female patients were included in the study. The mean age of the patients was $45.1 \pm 14.6$ years. Nephrectomy was made on the right side in 48 and left side on 42 of the kidneys. 24 of the patients who had nephrectomy had urinary system intervention story. When the etiologies of the pathologies causing nephrectomy are examined, $66(73 \%)$ patients had obstruction-causing stone, 15 (16.6\%) had ureteropelvic junction obstruction, $4(4,4 \%)$ had vesico-ureteral reflux, $3,3(3,3 \%)$ had preparation before kidney transplantation, 2 $(2,2 \%)$ had trauma. No function was observed in the kidney based on the scintigraphic examination made on 70 patients. When DMSA evaluations of all patients were examined, average kidney function was found as $4.3 \pm 9.6$. While laparoscopic nephrectomy was made in 47 of the patients $(52,2 \%)$, open nephrectomy was made in 43 $(47,8 \%)$. Average operation duration was $120 \pm 28.2$ min. While intraoperative difficulty of dissection was observed in hilus in $45(50 \%)$ patients and kidney parts other than hilus in $35(38,8 \%)$ patients, no difficulty of dissection was observed in 10 patients. Peroperative complication was observed in a total of 6 patients $(6,6 \%)$. While difference was observed in peroperative complications in the patients who had laparoscopic and open nephrectomy $(p=0.14)$, the patient ages, BMIs and operation durations were similar; $p=0.535, p=0.337$ and $p=0.074$ in order. Length of hospital stay was significantly shorter in the laparoscopic group (3.6 days vs. 1.7 days; $p<0.0001$ ). Mean postoperative pain score on postoperative first day after surgery was significantly lower laparoscopic group between 2 groups on the visual analog pain scale $(p<0.005)$. Non-steroidal anti-inflammatory drug (NSAID) and narcotic use was decreased in the laparoscopic group on postoperative first day $(p=0.008)$ (Table 1).

Based on the examination of final pathology specimens, chronic pyelonephritis was observed in 42 patients $(46,6 \%)$, tubulo-interstitial nephritis in 23 patients $(25,5 \%)$, atrophic kidney in 22 patients $(24.4 \%)$ and other pathologies in 3 patients $(3,3 \%)$. 
Table 1. Evaluation of patients undergoing open and laparoscopic nephrectomy.

\begin{tabular}{|c|c|c|c|c|}
\hline Variables & & $\begin{array}{l}\text { Laparoscopic Simple Nephrectomy } \\
\qquad(n=47)\end{array}$ & $\begin{array}{l}\text { Open Simple Nephrectomy } \\
\qquad(n=43)\end{array}$ & $P$ value \\
\hline Age & & $44.5 \pm 14.6$ & $47.3 \pm 15$ & 0.53 \\
\hline Gender & $\begin{array}{l}\text { Man } \\
\text { Woman }\end{array}$ & $\begin{array}{l}26(55.3 \%) \\
21(44.7 \%)\end{array}$ & $\begin{array}{l}13(30.2 \%) \\
30(69.7 \%)\end{array}$ & 0.2 \\
\hline Body-Mass Index $\left(\mathrm{kg} / \mathrm{m}^{2}\right)$ & & $26.03 \pm 1.32$ & $26.4 \pm 1.9$ & 0.33 \\
\hline Operation Time & & $143.4 \pm 26.4$ & $127.6 \pm 31.3$ & 0.74 \\
\hline \multirow[t]{2}{*}{ Complication } & & $4(8.5 \%)$ & $2(4.6 \%)$ & 0.14 \\
\hline & & $\begin{array}{c}\text { Bleeding }=2 \\
\text { Bowel } \\
\text { Injury }=1 \\
\text { Pneumothorax=1 }\end{array}$ & $\begin{array}{l}\text { Bleeding=1 } \\
\text { Bowel Injury=1 }\end{array}$ & \\
\hline Hospital Stay (day) & & $1.7 \pm 0.6$ & $3.6 \pm 2.2$ & 0.001 \\
\hline VAS score & & $3.1 \pm 2.1$ & $6.6 \pm 3.2$ & 0.005 \\
\hline $\begin{array}{l}\text { NSAID and Narcotic Drug } \\
\text { Use }(n, \%)\end{array}$ & & $20(42.5 \%)$ & $35(81.3 \%)$ & 0.008 \\
\hline
\end{tabular}

\section{DISCUSSION}

Nephrectomies to be made due to benign pathologies can be laparoscopic or open. Less postoperative pain, shorter hospitalization duration, early returning to daily life and better cosmetic results are the superiorities of laparoscopic surgery. Laparoscopic and open surgery has difficulties in obese patients. While retraction of fatty tissue may create problem in open surgery, trocar places may need to be changed due to the increasing distance in laparoscopic surgery ${ }^{[6]}$.

It was considered that etiologies indicating benign nephrectomy may have effects on the operation results. In a study made by Kurt et al ${ }^{[7]}$, patients who had laparoscopic simple nephrectomy were separated into two groups as those with and without inflammatory etiology and the surgery results were compared. In this small-scale study including 49 patients, no difference was detected in operation duration, peroperative bleeding, hospitalization duration, postoperative hemoglobin and creatinine change among the two groups ${ }^{[7]}$. In another study made by Manohar et al ${ }^{[8]}$, operation results of the patients who had laparoscopic and open surgery and simple nephrectomy due to inflammatory etiologies were compared. While pleura injury was observed significantly more in open nephrectomy group, visceral organ injury was observed more in laparoscopic nephrectomy group. Hospitalization duration and analgesic need were observed to be significantly high in open nephrectomy group again in this study, $4.3 \pm 0.8$ days vs $8.07 \pm 1.8$ days and $165 \pm 71.2 \mathrm{gr}$ diclofenac sodium vs $284 \pm 81 \mathrm{gr}$ in order. In our study, no difference was detected in the peroperative complications of the patients who had laparoscopic and open nephrectomy.

In a study made by Shah et al ${ }^{[9]}$, factors which may predicate intraoperative difficulty in laparoscopic simple nephrectomy were investigated. As a result, presence of pyonephrosis in preoperative imagings in multi-variate analysis and $\mathrm{BMI}$ under $25 \mathrm{~kg} / \mathrm{m}^{2}$ were found as the most important factors predicating intraoperative difficulty in laparoscopic simple nephrectomy. In addition, kidney intervention story in uni-variate analysis was found as a factor predicating intraoperative difficulty ${ }^{[9]}$. Ages and BMls of the patients who had laparoscopic and open nephrectomy were similar in our current study.

In a study made by Zelhof et al, the most common intraoperative complications in open surgery were 
reported as adjacent organ injury (intestine, spleen, liver, and pancreas), bleeding and pneumothorax. The most common postoperative complications were wound and lung infections. While intraoperative bleeding more than $500 \mathrm{~mL}$ was reported in $6.8 \%$ of the patients, blood transfusion was made for $4.8 \%$ of the patients. Intraoperative and postoperative complications, blood loss and returning to open were observed more than other indications in nephrectomies due to urinary system stone disease ${ }^{(1)}$. While bleeding and intestinal injury were observed in our study, bleeding, intestinal injury and pneumothorax were observed in laparoscopic surgery.

One of the advantages of laparoscopy versus open surgery is that it reduces the length of hospital stay and the need for postoperative NSAID and narcotic drugs is decreased. The fact that the incision is much smaller in laparoscopic surgery reduces the need for medication for pain control and shortens the postoperative time to mobilization. It was observed that the early mobilization of the patient also reduced the length of hospital stay ${ }^{(10)}$. In our study, it was found that the hospitalization stay and the need for postoperative pain medication was statistically lower in the laparoscopic surgery group.

\section{CONCLUSION}

Depending on the experience of the surgeon, laparoscopic and open surgery presents similar surgical results in simple nephrectomies made due to surgical benign causes. Recovery speed, cosmetic results and less pain in postoperative period may support laparoscopic surgery.

Ethics Committee Approval: Bakırköy Dr. Approval was obtained from the Sadi Konuk Training and
Research Hospital Clinical Research Ethics Committee (2019/325, 02.09.2019).

Conflict of Interest: The author declares that he has no conflict of interest.

Funding: No financial support was received.

Informed Consent: Informed consent was not obtained since the study is retrospective.

\section{REFERENCES}

1. Zelhof B, Mclntyre IG, Fowler SM, Napier-Hemy RD, Burke DM, Grey BR, British Association of Urological S. Nephrectomy for benign disease in the UK: results from the British Association of Urological Surgeons nephrectomy database. BJU Int 2016;117(1):138-44. https://doi.org/10.1111/bju.13141

2. Connolly SS, O'Brien MF, Kunni IM, Phelan E, Conroy R, Thornhill JA, Grainger R. Is simple nephrectomy truly simple? Comparison with the radical alternative. Ir J Med Sci 2011;180 (1):177-9. https://doi.org/10.1007/s11845-010-0651-7

3. McDougall EM, Clayman RV. Laparoscopic nephrectomy for benign disease: comparison of the transperitoneal and retroperitoneal approaches. J Endourol 1996;10 (1):45-9. https://doi.org/10.1089/end.1996.10.45

4. EAU Guidelines on Renal Cell Carcinoma, 2019

5. Malignant Renal Tumors. Steven C. Campell MD, PhD and Brian R. Lane MD, PhD Campell Walsh Urology, 57, 13141364.e14.

6. Gupta NP, Gautam G. Laparoscopic nephrectomy for benign non functioning kidneys. J Minim Access Surg. 2005;1 (4):14954.

https://doi.org/10.4103/0972-9941.19261

7. Kurt O, Buldu I, Turan C, Yazici CM. Does laparoscopic transperitoneal simple nephrectomy for inflammatory and noninflammatory kidneys differ? Springerplus 2016;5(1):1358. https://doi.org/10.1186/s40064-016-2945-3

8. Manohar T, Desai M, Desai M. Laparoscopic nephrectomy for benign and inflammatory conditions. J Endourol 2007;21 (11):1323-8. https://doi.org/10.1089/end.2007.9883

9. Shah P, Ganpule A, Mishra S, Sabnis R, Desai MR. Prospective study of preoperative factors predicting intraoperative difficulty during laparoscopic transperitoneal simple nephrectomy. Urol Ann 2015;7(4):448-53. https://doi.org/10.4103/0974-7796.152045

10. Shuford MD, McDougall EM, Chang SS, LaFleur BJ et al. Complications of Contemporary Radical Nephrectomy: Comparison of Open vs. Laparoscopic Approach. Urol Oncol, 2004;22(2):121-6.

https://doi.org/10.1016/S1078-1439(03)00137-6 